\title{
Perlindungan Hukum terhadap Hak Pekerja Perempuan Di Masa Pandemi Covid-19
}

\author{
Conie Pania Putri \\ Program Pascasarjana Magister Ilmu Hukum, Universitas Kader Bangsa, Palembang \\ Correspondence email: coniepania79@gmail.com
}

\begin{abstract}
Abstrak. Dunia saat ini telah dihadapi oleh pandemic global covid-19, termasuk di Indonesia pandemic ini sangat meresahkan masyarakat. Pembangunan ketenagakerjaan harus diatur sedemikian rupa sehingga terpenuhi hak-hak dan perlindungan yang mendasar bagi tenaga kerja khususnya bagi pekerja perempuan sehingga dapat mewujudkan kondisi yang kondusif. Tujuan dari tulisan ini yaitu untuk mengetahui kebijakan yang dikeluarkan oleh perusahaan untuk para pekerja khususnya pekerja perempuan pada masa pandemic covid-19. Metode penulisan ini yaitu penelitan kepustakaan (library research), yaitu serangkaian penelitian yang berkenaan dengan metode pengumpulan data pustaka, atau penelitian yang obyek penelitiannya digali melalui beragam informasi kepustakaan. Hasil yang didapat dalam tulisan ini kebijakan perusahaan yang melakukan pemutusan hubungan kerja terhadap perempuan dimasa pandemi covid -19 mendapat perlindunganUndang-Undang Nomor 13 Tahun 2003 tentang Ketenagakerjaan, kerugian yang diakibatkan oleh perusahaan belum mencapai 2 tahun maka perusahaan tidak bisa memutus hubungan kerja begitu saja, maka perlu adanya upaya lain yang diberikan oleh perusahaan atau pemerintah dalam menanggulangi dampak covid-19 kepada para pekerja yang di PHK agar dapat membatasi waktu kerja/lembur dan para pekerja bisa dirumahkan dengan tidak memutus hubungan kerja. Saran yang diharapkan hendaknya pemerintah mengawasi dan bertindak tegas terhadap perusahaan-perusahaan yang memperkerjakan tenaga kerja wanita.
\end{abstract}

Kata Kunci: Covid-19; Pekerja; Perempuan.

Abstract. The world is currently being faced by a global covid-19 pandemic, including in Indonesia this pandemic is very disturbing to the public. Manpower development must be regulated in such a way that basic rights and protections for workers are fulfilled, especially for women workers so as to create conducive conditions. The purpose of this paper is to find out the policies issued by companies for workers, especially women workers during the Covid-19 pandemic. This writing method is library research, which is a series of research related to library data collection methods, or research where the object of research is excavated through a variety of library information. The results obtained in this paper are that the company policies that terminate employment of women during the Covid-19 pandemic are protected by Law Number 13 of 2003 concerning Manpower, the losses caused by the company have not reached 2 years, the company cannot simply terminate the work relationship, Then there needs to be other efforts provided by companies or the government in overcoming the impact of Covid-19 on laid-off workers so that they can limit working time / overtime and workers can be sent home without breaking the work relationship The suggestion is expected that the government should supervise and act decisively against companies that employ female workers.

Keywords: Covid-19; Workers; Women.

\section{PENDAHULUAN}

Dunia sedang menghadapi permasalahan yang sangat krusial dengan kehadiran Covid-19 yang telah menyebarluas ke seluruh dunia termasuk Indonesia. Dilematis berbagai negara dalam menanggulangi covid-19 membuat pemerintahan bahkan masyarakat merasakan keresahan dan kerugian yang berdampak pada kesehatan maupun perekonomian. Sehingga, pemerintah perlu mengeluarkan kebijakan yang diatur dalam PP No. 21 Tahun 2020 tentang PSBB (Pembatasan Sosial Berskala Besar) dengan tujuan untuk memutus rantai penyebaran Covid-19.

Kebijakan tersebut, membuat beberapa perusahaan mengambil langkah untuk mengurangi kerugian akibat Covid-19. Salah satu langkah yang diambil oleh beberapa perusahaan di Indonesia yaitu harus melakukan Pemutusan Hubungan Kerja (PHK) pada para karyawan yang bekerja di perusahaan terse-but. Hal ini sejalan dengan Pasal 164 dan 165 Undang-Undang No. 13 Tahun 2003 tentang Ketenagakerjaan yang kurang lebih frasanya menyatakan bahwa suatu perusahaan berhak memutus hubungan kerja terhadap pekerja apabila suatu perusahaan mengalami kerugian tidak terkecuali terhadap perempuan yang palingn rentan dalam Pemutusan Hubungan Kerja tersebut.

Negara yang seharusnya menjadi penjamin hak terhadap warganya justru sengaja membiarkan berbagai kasus pelanggaran terhadap kaum buruh tetap saja terjadi. Namun pada umumnya, beberapa perusahaan yang memutus hubungan kerja di masa pandemi Covid-19 ini seringkali menggunakan alasan force majeure, padahal perusahaan tersebut masih berproduksi seperti biasanya.Padahal dalam konstitusi ada jaminan terhadap hak warga Negara untuk berhak atas pekerjaan dan penghidupan yang layak.

Didalam Undang-Undang Dasar 1945, terdapat hak-hak konstiusional yang harus dipenuhi salah satunya pemenuhan hak perempuan khususnya pekerja perempuan.Berdasarkan Pasal 1 Undang-undang Nomor 13 Tahun 2003 Tentang Ketenagakerjaan dinyatakan bahwa "Tenaga kerja adalah setiap orang yang mampu melakukan 
pekerjaan guna menghasilkan barang/ atau jasa baik untuk memenuhi kebutuhan sendiri maupun masyarakat". Berdasarkan pengertian tersebut maka yang dimaksud dengan pekerja adalah setiap orang yang bekerja dengan menerima upah atau imbalan dalam bentuk lain ${ }^{1}$.

Secara normatif beberapa ketentuan perundang-undangan. perburuhan/ketenagakerjaan nasional yang saat ini masih beraku dirasa kurang memberikan perlindungan bagi pekerja. ${ }^{2}$ Terutama pekerja perempuan. Bila ditinjau secara normatif Undang-Undang Dasar Negara Republik Indonesia Tahun 1945 menjamin hak setiap warga Negara untuk memperoleh pekerjaan berdasarkan Pasal 27 ayat (2) yang menyatakan Tiap-tiap warga negara berhak atas pekerjaan dan penghidupan yang layak bagi kemanusiaan. Hal ini kemudian dipertegas kembali dalam Undang-Undang Dasar Negara Republik Indonesia Tahun 1945 (hasil amandemen kedua) Bab XA tentang Hak Asasi Manusia. Pada Pasal 28 D mengamanatkan bahwa "Setiap orang berhak untuk bekerja serta mendapat imbalan dan perlakuan yang adil dan layak dalam hubungan kerja". ${ }^{3}$ Selanjutnya dalam Pasal 28 I ayat (4) menegaskan bahwa perlindungan (protection), pemajuan (furtherance), penegakan (enforcement) dan pemenuhan (fulfilment) hak asasi manusia adalah tanggung jawab Negara. ${ }^{4}$

Oleh karena itu, ketidakjelasan terkait Pemutusan Hubungan Kerja oleh perusahaan di masa pandemic Covid-19 menjadi titik fokus penulis untuk membahas kebijakan yang dikeluarkan oleh perusahaan untuk para pekerja khususnya pekerja perempuan, maka perlu adanya perlindungan hukum bagi para pekerja perempuan tersebut.

\section{METODE}

Jenis penelitian ini adalah penelitan kepustakaan (library research), yaitu serangkaian penelitian yang berkenaan dengan metode pengumpulan data pustaka, atau penelitian yang obyek penelitiannya digali melalui beragam informasi kepustakaan (buku, ensiklopedi, jurnal ilmiah, dan dokumen). Penelitian kepustakaan atau kajian literatur (literature review, literature research) merupakan penelitian yang mengkaji atau meninjau secara kritis pengetahuan, gagasan, atau temuan yang terdapat di dalam tubuh literatur berorientasi akademik (academic-oriented literature), serta merumuskan kontribusi teoritis dan metodologisnya untuk topik tertentu.

\section{HASIL DAN PEMBAHASAN}

Dalam dinamika ketenagakerjaan di Indonesia, hubungan kerja tidak serta merta berjalan dengan optimal atau dapat dikatakan mengalami permasalahan yang bisa disebabkan oleh si pekerja atau pun perusahaan. Diantara pekerja yang merasa dirugikan dengan kebijakan dari perusahaan, maupun perusahaan yang merasa dirugikan dengan kelalaian para pekerja. Dari faktor tersebut, maka dapat memungkinkan adanya perselisihan antara pekerja dan pengusaha dalam hal Pemutusan Hubungan Kerja (PHK) ditambah dengan adanya pandemi Covid-19 yang telah menyebar keseluruh dunia termasuk Indonesia. Sehingga, beberapa perusahaan mengeluarkan kebijakan untuk memutus hubungan kerja dengan beberapa pekerja yang dirasa mengakibatkan menambah kerugian perusahaan.

Berdasarkan Undang-Undang Nomor 13 Tahun 2003 tentang Ketenagakerjaan, kerugian yang diakibatkan oleh perusahaan belum mencapai 2 tahun maka perusahaan tidak bisa memutus hubungan kerja begitu saja. Maka perlu adanya upaya lain yang diberikan oleh perusahaan atau pemerintah dalam menanggulangi dampak Covid-19 kepada para pekerja yang di PHK agar dapat membatasi waktu kerja/lembur dan para pekerja bisa dirumahkan dengan tidak memutus hubungan ker-ja. Dengan hal tersebut dapat membantu pemerintah untuk mengurangi angka pengangguran dan dapat membantu pemerintah me-numbuhkan perekonomian dikala pandemi Covid-19.

Undang-Undang Nomor 13 Tahun 2003 tentang ketenagakerjaan merupakan salah satu solusi dalam perlindungan buruh maupun majikan tentang hak dan kewajiban masing-masing pihak. Perlindungan buruh diatur di dalam Undang-Undang Nomor 13 Tahun 2003 tentang Ketenagakerjaan Pasal 67 sampai dengan Pasal 101 meliputi perlindungan buruh penyandang cacat, anak, perempuan, waktu kerja, keselamatan dan kesehatan kerja, pengupahan dan kesejahteraan. Menelaah Undang-Undang Nomor 13 Tahun 2003 berarti dalam mengatur hak dan kewajiban bagi para tenaga kerja maupun para pengusaha di dalam melaksanakan suatu mekanisme proses produksi.

Selain itu keberadaan tenaga kerja perempuan yang selalu mendapat perlakuan tidak adil sehingga membutuhkan perlindungan hukum dan Hak Asasi Manusia. Hak asasi manusia sendiri dewasa ini dianggap sebagai etika politik modern dengan gagasan inti adanya tuntutan moral yang menyangkut bagaimana manusia wajib memperlakukan manusia, sehingga secara potensial amat kuat untuk dilindungi orang dan kelompok yang lemah terhadap kewenangan mereka yang kuat karena kedudukan, usia, status dan lainnya.

${ }^{1}$ Pengertian pekerja/buruh berdasarkan Pasal 1 butir 2 Undang-undang Nomor 13 Tahun 2003 Tentang Ketenagakerjaan. Lembaran Negara Republik Indonesia Tahun 2003 Nomor 39

${ }^{2}$ Lalu Husni, Pengantar Hukum Ketenagakerjaan IndonesiaEdisi Revisi, PT, RajaGrafindo Persada, Jakarta, 2003, hlm. 7

${ }^{3}$ Ibid hlm. 10

${ }^{4}$ Ibid 
Menurut Saparinah Sadli ${ }^{5}$ defenisi hak asasi manusia yang dianut dalam piagam hak asasi manusia secara kodrati universal dan abadi sebagai anugrah Tuhan Yang Maha Esa, meliputi hak untuk hidup, hak berkeluarga, hak mengembangkan diri hak keamanan dan hak kesejatraan, yang oleh karena itu tidak boleh diabaikan atau dirampas oleh siapapun. Sedangkan di dalam Pasal 1 ayat (1) dari Undang-Undang Nomor 39 Tahun 1999 tentang Hak Asasi Manusia mendefenisikan hak asasi manusia sebagai seperangkat hak yang melekat pada hakekat keberadaan manusia sebagai mahluk Tuhan Yang Maha Esa, dan merupakan anugrahNYA yang wajib dihormati, dijunjung tinggi dan dilindungi oleh Negara, hukum, pemerintah dan setiap orang demi kehormatan serta perlindungan harkat dan martabat manusia yang selanjutnya ada juga dalam Pasal 38 Undang-Undang Nomor 39 Tahun 1999 tentang Hak Asasi Manusia yang mengatakan bahwa:

1) Setiap warga negara, sesuai dengan bakat, kecakapan, kemampuan, berhak atas pekerjaan yang layak,

2) Setiap orang berhak dengan bebas memilih pekerjaan yang disukainya dan berhak pula atas syarat-syarat ketenagakerjaan yang adil,

3) Setiap orang, baik pria maupun wanita yang melakukan pekerjaan yang sama, sebanding, setara, dan serupa, berhak atas upah serta syarat-syarat perjanjian kerja yang sama,

4) Setiap orang, baik pria maupun wanita, dalam melakukan pekerjaan yang sepadan dengan martabat kemanusiaannya berhak atas upah yang adil sesuai dengan prestasinya dan dapat menjamin kelangsungan kehidupan keluarganya.

Ini berarti bahwa para pekerja khususnya perempuan mempunyai hak untuk mendapatkan perlindungan hukum demi mendapatkan pekerjaan yang layak untuk keluarganya. Kemudian penjabaran mengenai Hak Asasi Manusia yang dituangkan dalam ketentuan Undang-Undang Dasar 1945 terdapat dalam pasal 28. Dalam Pasal 28 A UndangUndang Dasar 1945 menyebutkan bahwa "Setiap orang berhak untuk hidup serta berhak mempertahankan hidup dan kehidupannya".

Pasal 28 D Undang-Undang Dasar 1945 menyebutkan bahwa (1). Setiap orang berhak atas pengakuan, jaminan, perlindungan dan kepastian hukum yang adil serta perlakuan yang sama dihadapan hukum. Ayat (2) menyebutkan bahwa Setiap orang berhak untuk bekerja serta mendapat imbalan dan perlakuan yang adil dan layak dalam hubungan kerja.Pasal 28 G Undang-Undang Dasar 1945 menyebutkan bahwa (1) Setiap orang berhak atas perlindungan diri pribadi, keluarga, kehormatan, martabat dan harta benda yang dibawah kekuasaannya, serta berhak atas rasa aman dan perlindungan dari ancaman ketakutan untuk berbuat atau tidak berbuat sesuatu yang merupakan hak asasi. (2). Setiap orang berhak untuk bebas dari penyiksaan atau perlakuan yang merendahkan derajat martabat manusia dan berhak memperoleh suaka politik dari negara lain.

Pasal $28 \mathrm{H}$ ayat (3) Undang-Undang Dasar 1945 menyebutkan bahwa Setiap orang berhak atas jaminan sosial yang memungkinkan pengembangan dirinya secara utuh sebagai manusia yang bermartabat.Hak adalah kepentingan yang dilindungi, sedangkan kepentingan adalah tuntutan perorangan atau kelompok yang diharapkan untuk dipenuhi. Kepentingan pada hakekatnya, mengandung kekuasaan yang dijamin dan dilindungi oleh hukum dalam melaksanakannya. Apa yang dinamakan hak itu sah, karena dilindungi oleh sistim hukum ${ }^{6}$.

Pengakuan dan perlindungan hak asasi manusia yang dijadikan sebagai unsur utama negara hukum merupakan jabaran dari konstitusi, bahwa negara ini berdasarkan atas hukum dan tidak berdasarkan atas kekuasaan maka perlindungan merupakan jaminan kalau harkat dan martabat manusia memperoleh tempat yang layak di depan hukum dan pemerintah, dan dalam posisi ini manusia manusia merupakan subjek yang mendapat jaminan perlindungan hakhak kemanusiannya.

Tidak kalah pentingnya adalah perlindungan tenaga kerja yang bertujuan agar bisa menjamin hak-hak dasar pekerja/buruh dan menjamin kesempatan serta perlakuan tanpa diskriminasi. Hal ini merupakan esensi dari disusunnya undang-undang ketenagakerjaan yaitu mewujudkan kesejahteraan para pekerja/buruh yang akan berimbas terhadap kemajuan dunia usaha di Indonesia. Setiap perempuan mempunyai hak-hak khusus yang berkaitan dengan hak asasi manusia yang diakui dan dilindungi oleh undang-undang. Hak Perempuan dimana perempuan dikategorikan dalam kelompok rentan yang mendapat tempat khusus dalam pengaturan jaminan perlindungan hak asasi manusia. Pada umunya pemberian hak bagi perempuan sama dengan hak-hak lain seperti yang telah disebutkan dalam pasalpasal Undang-Undang Hak-Hak Asasi Manusia namun dengan alasan tadi maka lebih dipertegas lagi. Asas yang mendasari hak bagi perempuan diantaranya hak perspektif gender dan anti diskriminasi dalam artian memiliki hak yang seperti kaum laki-laki dalam bidang pendidikan, hukum, pekerjaan, politik, kewarganegaraan dan hak dalam perkawinan serta kewajibannya. ${ }^{7}$ Dasar hukum atas hak tersebut dalam instrumen internasional dapat ditemukan dalam

${ }^{5}$ Saprinah Sadli, 2000, dalam Barzah Latupono, Perlindungan Hukum Dan Hak Asasi Manusia Terhadap Pekerja Kontrak (Outsourcing) Di Kota Ambo, Jurnal Sasi Vol. 17 No. 3 Bulan Juli-September 2011 hlm. 66.

6 Sudikno Mertokusuma, Mengenal Hukum Suatu Pengantar, Liberty, Yogyakarta, 1996, hlm. 41

${ }^{7}$ Rhona K. M Smith, at.al. Hukum Hak Asasi Manusia, Knut D. Asplund, Suparman Marzuki, EkoRiyadi (Editor), PUSHAM UII, Yogyakarta, 2008, hlm. 269 
Pasal 23 DUHAM, Pasal 6 ayat (1), 7 dan Pasal 8 ayat (1) butir (a) dan (b) Konvensi Internasional tentang Hak-Hak Ekonomi Sosial dan Budaya, dimana didalamnya diatur hak-hak seseorang atas suatu profesi dan pekerjaan yang berlaku bagi semua orang.

Pasal 11 CEDAW Pasal 3 Konvensi tentang Hak-Hak Politik Perempuan, dapat ditemukan adanya perlindungan hak tersebut yang diberlakukan lebih khusus kepada semua perempuan. Dalam instrumen nasional mengenai hal ini dapat ditemukan dalam Pasal 76 Undang-Undang Nomor 13 Tahun 2003 tentang Ketenagakerjaan dan Pasal 49 (1) Undang-Undang Nomor 39 Tahun 1999 tentang HAM. Dalam Pasal 49 (1) UU HAM disebutkan bahwa "Wanita berhak untuk memilih, dipilih, diangkat dalam pekerjaan, jabatan, dan profesi sesuai dengan persyaratan dan peraturan perundang-undangan".Pada Konvensi CEDAW (Convention on the Elimination of All of Discrimination Againt Women) Pasal terpenting dalam konvensi ini adalah Pasal 4 dan Pasal 11. Pada Pasal 4 menjelaskan tentang affirmative action atau diskriminasi posotif bagi perempuan. Sedangkan pada Pasal 11 dijelaskan mengenai aturan tentang kewajiban Negara untuk menjamin ketiadaan diskriminasi bagi perempuan di tempat kerja. ${ }^{8} \mathrm{Hak}$ yang dimiliki oleh seorang perempuan, baik karena ia seorang manusia maupun sebagai seorang perempuan, dalam khasanah hukum hak asasi manusia dapat ditemui pengaturannya dalam berbagai sistem hukum tentang hak asasi manusia. Dalam pengertian tersebut dijelaskan bahwa pengaturan mengenai pengakuan atas hak seorang perempuan terdapat dalam berbagai sistem hukum tentang hak asasi manusia. Sistem hukum tentang hak asasi manusia yang dimaksud adalah system hukum hak asasi manusia baik yang terdapat dalam ranah internasional maupun nasional. Khusus mengenai hak-hak perempuan yang terdapat dalam sistem hukum tentang hak asasi manusia dapat ditemukan baik secara eksplisit maupun implisit. Dengan penggunaan kata-kata yang umum terkadang membuat pengaturan tersebut menjadi berlaku pula untuk kepentingan perempuan. ${ }^{9}$

Dalam hal ini dapat dijadikan dasar sebagai perlindungan dan pengakuan atas hak-hak perempuan. Seseorang perempuan terkadang mendapat diskriminasi dan anggapan sebelah mata, diskrimansi dapat terjadi baik dalam kehidupan pekerjaan, keluarga hingga kehidupan yang dilaluinya dalam masyarakat. Dengan adanya diskriminasi inilah kemudian banyak pihak terutama perempuan sendiri menyadari pentingnya mengangkat isu hak perempuan sebagai salah satu jenis hak asasi manusia yang harus dapat diakui dan dijamin perlindungannya.Berkaitan dengan hak perempuan di bidang profesi dan ketenagakerjaan, terdapat hak-hak yang harus didapatkan perempuan baik sebelum, saat, maupun sesudah melakukan pekerjaan. Sebelum mendapat pekerjaan, seorang perempuan mempunyai hak untuk diberikan kesempatan yang sama dengan pria untuk mendapatkan pekerjaan yang seseuai dengan kemampuannya, sehingga mereka perempuan harus dapat dilakukan seleksi terhadapnya tanpa ada diskriminasi apapun. Saat mendapat pekerjaan, seorang perempuan juga mempunyai hak-hak yang harus dipenuhi, yaitu mendapatkan upah sesuai dengan pekerjaannya, mendapatkan kondisi kerja yag aman dan sehat, kesempatan yang sama untuk dapat meningkatkan pekerjaannya ke tingkat yang lebih tinggi, termasuk juga hak untuk mendapatkan pelatihan untuk meningkatkan kualitas pekerjaannya. ${ }^{10}$ Setelah mendapat pekerjaan, tentunya ada saatnya ketika perempuan harus berhenti dan meninggalkan pekerjaannya. Maka ketika pekerjaan itu berakhir, seorang perempuan juga mempunyai hak untuk mendapatkan pesangon yang adil dan sesuai dengan kinerja dan kualitas pekerjaan yang dilakukannya.

\section{SIMPULAN}

Kebijakan perusahaan yang melakukan pemutusan hubungan kerja terhadap perempuan dimasa Pandemi Covid -19 mendapat perlindunganUndang-Undang Nomor 13 Tahun 2003 tentang Ketenagakerjaan, kerugian yang diakibatkan oleh perusahaan belum mencapai 2 tahun maka perusahaan tidak bisa memutus hubungan kerja begitu saja. Maka perlu adanya upaya lain yang diberikan oleh perusahaan atau pemerintah dalam menanggulangi dampak Covid-19 kepada para pekerja yang di PHK agar dapat membatasi waktu kerja/lembur dan para pekerja bisa dirumahkan dengan tidak memutus hubungan kerja.

\section{DAFTAR PUSTAKA}

Agus Midah Hukum Perlindungan Perempuan dan Anak (Buruh Perempuan di sector Formal)n, USAID The Asia Foundation dan Kemitraan.

Agus Santoso, Hukum, Moral dan Keadilan sebagai Kajian Filsafat hukum, PT. Fajar Interpratama Mandiri, Jakarta, Cetakan ke-2, 2012.

Abdul Hakim, Dasar-Dasar Hukum Ketenagakerjaan Indonesia, PT. Citra Aditya Bakti, Bandung, 2009.

\footnotetext{
${ }^{8}$ Agus Midah Hukum Perlindungan Perempuan dan Anak (Buruh Perempuan di sector Formal)n, USAID The Asia Foundation dan Kemitraan, hlm 537

${ }^{9}$ https://andhikafrancisco.wordpress.com/2013/04/22/makalah-hukum-perlindungan-pekerja-wanita, diakses Tanggal 9 September 2020

${ }^{10}$ Abdul Hakim, Dasar-Dasar Hukum Ketenagakerjaan Indonesia, PT. Citra Aditya Bakti, Bandung, 2009, hlm. 2
} 
Bernand L. Tanya, Teori Hukum Startegi Tertib Manusia Lintas Ruang dan Generasi, Cetakan Pertama Agustus 2006, Surabaya.

Keputusan menteri transmigrasi Republik Indonesia Kep. 224/Men/2003 tentang kewajiban pengusaha yang mempekerjakan pekerja/buruh perempuan antara pukul 23 sampai pukul 07.00.

Lalu Husni, Pengantar Hukum Ketenagakerjaan IndonesiaEdisi Revisi, PT, RajaGrafindo Persada, Jakarta, 2003.

Peraturan Menteri Tenaga kerja Nomor 8 Permen/1989 tentang syarat-syarat kerja malam dan tata cara mempekerjakan pekerja perempuan pada malam hari,

Rhona K. M Smith, at.al. Hukum Hak Asasi Manusia, Knut D. Asplund, Suparman Marzuki, Eko Riyadi (Editor), PUSHAM UII, Yogyakarta, 2008.

Saprinah Sadli, 2000:82, dalam Barzah Latupono, Perlindungan Hukum Dan Hak Asasi Manusia Terhadap Pekerja Kontrak (Outsourcing) Di Kota Ambo, Jurnal Sasi Vol. 17 No. 3 Bulan Juli-September 2011

Sudikno Mertokusuma, Mengenal Hukum Suatu Pengantar, Liberty, Yogyakarta, 1996.

Undang-Undang Dasar Negara Republik Indonesia Tahun 1945.

Undang-undang Nomor 13 Tahun 2003 Tentang Ketenagakerjaan.

Undang-undang Nomor 8 Tahun 1981 tentang Perlindungan Upah. 